\title{
Fat content in fermented milk beverages: determination by the Gerber method
}

\section{Determinação do teor de gordura de bebidas lácteas fermentadas pelo método de Gerber}

\author{
Elisa Helena Paz Andrade ${ }^{1 *}$; Leorges Moraes da Fonseca ${ }^{1} ;$ Marcelo Resende de \\ Souza'; Cláudia Freire de Andrade Morais Penna; Mônica Maria Oliveira Pinho \\ Cerqueira $^{1}$; Mônica de Oliveira Leite ${ }^{1}$
}

\section{Highlights}

The Gerber method can be used to determine the fat content in fermented milk beverages. Roese-Gottlieb was used as a reference method.

The fat contents obtained by both methods were equivalent. .

\begin{abstract}
Fermented milk beverage is a product containing milk, whey and/or other ingredients, fermented by specific microorganisms and/or added with fermented milks. Fat determination in this product is important to quality control and inspection. The Gerber method is used worldwide as a simple and rapid method for fat content analysis in raw and processed milks. In Brazil, Roese-Gottlieb is the official method for analysis of fat content in milk beverages. However, the use of Gerber method for fat content determination in fermented milk beverages is widespread throughout the industry in the country. Several authors have tested the use of Gerber method for some dairy products, but there is no report on this evaluation for fermented milk beverages. In this context, the objectives of this work were to determine the fat content of fermented milk beverages by the Gerber method and evaluate the performance of this test, using Roese-Gottlieb as a reference method. Thirty samples of fermented milk beverages were analyzed by both methods. The fat contents ranged from 1.25 to $2.40 \%$ by the Gerber method and from 1.24 to $2.50 \%$ by the Roese-Gottlieb method. There was no difference ( $p>0.05$ ) between the methods. The Gerber method can be used to determine the fat content of fermented milk beverages, without prejudice to the results obtained.
\end{abstract}

Key words: Dairy product. Proximate composition. Roese-Gottlieb method. Inspection.

1 Profs. Drs., Department of Technology and Inspection of Animal Products, Veterinary School, Universidade Federal de Minas Gerais, UFMG, Belo Horizonte, MG, Brazil. E-mail: elisahpandrade@yahoo.com.br; leorges@ufmg.br; marceloresende51@gmail.com; claudiapenna@ufmg.br; monicapinhocerqueira@gmail.com; monicaoliveiraleite@ gmail.com

* Author for correspondence

Received: Apr. 20, 2021 - Approved: Oct. 07, 2021 


\section{Resumo}

Bebida láctea fermentada é um produto que contém leite, soro e/ou outros ingredientes, fermentada pela ação de microrganismos específicos e/ou adicionada de leites fermentados. A determinação do teor de gordura nesse produto é importante para o controle de qualidade e inspeção. O método de Gerber é utilizado em todo o mundo como um método simples e rápido para a análise do teor de gordura em leites cru e processado. No Brasil, Roese-Gottlieb é o método oficial para análise do teor de gordura em bebidas lácteas. No entano, a utilização do método de Gerber para determinação do teor de gordura em bebidas lácteas é frequente nas indústrias do país. Vários autores testaram o método de Gerber para alguns products lácteos, mas não há relato dessa avaliação para bebidas lácteas fermentadas. Tendo em vista o que foi exposto, os objetivos deste trabalho foram determinar o teor de gordura de bebidas lácteas fermentadas pelo método de Gerber e avaliar o desempenho desse teste, utilizando Roese-Gottlieb como método de referência. Trinta amostras de bebidas lácteas fermentadas foram analisadas por ambos os métodos. Os teores de gordura variaram de 1,25 a 2,40\% pelo método de Gerber e de 1,24 a 2,50\% pelo método de Roese-Gottlieb. Não foi constatada diferença $(p>0,05)$ entre os métodos. O método de Gerber pode ser utilizado para determinação do teor de gordura de bebidas lácteas fermentadas, sem prejuízo dos resultados obtidos.

Palavras-chave: Produto lácteo. Composição centesimal. Método de Roese-Gottlieb. Inspeção.

In Brazil, milk beverage is a product made by mixing milk and cheese whey, with the optional addition of other food ingredients, vegetable fat, fermented milk, starter culture, and other dairy products, depending on the type of milk beverage. Milk basis must represent at least $51 \%(\mathrm{~m} / \mathrm{m})$ of the total ingredients present in the product. A milk beverage is classified as fermented when the mixture milk: whey is added with specific starter microorganisms and/or with fermented milk (Ministério da Agricultura, Pecuária e Abastecimento [MAPA], 2005).

Fat content is usually lower in milk beverages than milk and fermented milks due to the addition of whey (Oliveira, 2006; Cunha, Castro, Barreto, Benedet \& Prudêncio, 2008). Considering milk beverages without additions or with additions which has the same or similar organoleptic characteristics to the milk beverages without additions, the minimum legal specification for fat content is
$2.00 \%$. There is no standard for fat content of fermented milk beverages with additions established for the legislation (MAPA, 2005). The lack of this requirement, together with labeling information, nutritional calculation and quality control, reinforce the need for fat determination in fermented milk beverages.

Roese-Gottlieb is a gravimetric reference method for milk fat analysis based on fat extraction with a mixture of ethers. This method is also considered the official for analysis of fat content in milk beverages. (Association of Official Analytical Chemists [AOAC], 2012; MAPA, 2018). However, the execution of Roese-Gottlieb method demands specific glassware and equipment and takes a long analysis time.

Butyrometric methods include the Gerber fat test, which is an approved routine volumetric method for fluid milk fat analysis (MAPA, 2018). Since Gerber is a cheaper and 
faster method than those based on ether extraction, it has been used worldwide for several products, including fermented milk beverages (Almeida, Bonassi, \& Roça, 2001; Kleyn, Lynch, Barbano, Bloom, \& Mitchell, 2001; Oliveira, 2006; Cunha et al., 2008; Andrade et al., 2015), however with a little scientific underpinning of precision and accuracy.

The objectives of the current work were to determine the fat content of fermented milk beverages by the Gerber method and evaluate the performance of this test, using RoeseGottlieb as a reference method.

Thirty retail samples of fermented milk beverages were obtained in main local supermarkets from Belo Horizonte, Minas Gerais, Brazil. Sampling included six fermented milk beverages of different batches of five distinct Federally inspected brands collected during a four-month period in 2009. Samples were kept under refrigeration, until they were analyzed.

The analyses were carried out in the Federal Agricultural Defense Laboratory, located in Pedro Leopoldo, MG, Brazil (Laboratório Nacional Agropecuário/ Laboratório Federal de Defesa Agropecuária LFDA de Minas Gerais). After homogenization, $11 \mathrm{~mL}$ and $5 \mathrm{~g}$ were taken from each of the thirty samples to perform Gerber (MAPA, 2018) and Roese-Gottlieb (International Organization for Standardization/ International Dairy Federation, 2010; MAPA, 2018) methods, respectively. The analyses were realized in duplicate for each sample and test.

The Gerber test is based on the visual reading of the fat in a Gerber milktester butyrometer column, after sulfuric acid hydrolysis of milk components, and centrifugation. Brazilian Gerber procedure is similar to AOAC International, except for using an $11 \mathrm{~mL}$ pipette to measure the sample, instead of weighing. The volumetric measurement of the sample is recommended by the International Dairy Federation (International Organization for Standardization I Interantional Dairy Federation [ISO/IDF], 2008).

In the Roese-Gottlieb method, fat is extracted with a mixture of ethers from a known weight of the sample. The ether extract is decanted into pre-weighed dry weighing dish, and ether is evaporated. The extracted fat is dried to constant weight, and the result is expressed as percentage of fat by weight (MAPA, 2018; AOAC, 2012).

Statistical analyses were descriptive and methods comparison was based on Student's t-test for samples at a significance level of 0.05 (Sampaio, 2002) using SAS software 8.0 (SAS Institute Inc, Cary, Carolina do Norte, EUA). Correlation analysis was also performed between the fat contents obtained by each method using Minitab Statistical Software 16.0 (Minitab, LLC, State College, Pensilvânia, EUA).

The fat content of fermented milk beverages determined by Gerber method ranged from 1.25 to $2.40 \%$, with a mean value of $1.77 \pm 0.33 \%$ (Table 1 ). Previous reports using the Gerber method showed similar results. Almeida et al. (2001) produced fermented milk beverages with 30, 40 and $50 \%$ of whey and found that the mean values of fat content were 1.92, 1.76 and 1.59\%, respectively. Oliveira (2006) evaluated the fat content of fermented milk beverages with 30 , 40 and $50 \%$ of whey and encountered 2.60 , $2.00,1.60 \%$ for them, respectively. The fat content of a fermented milk beverage with 
$30 \%$ whey prepared by Cunha et al. (2008) was $1.91 \%$. A research carried out with samples of fermented milk beverages belonging to five brands collected in supermarkets from Belo Horizonte demonstrated that the mean values of fat content were 1.24, 1.71, 1.76, 1.80 and 1.98\% (Andrade et al., 2015).

The fat contents determined by RoeseGottlieb method ranged from 1.24 to $2.50 \%$, with a mean value of $1.83 \pm 0.32 \%$ (Table 1 ). These results agreed with those obtained by A. V. S. Costa et al. (2013), although these authors found lower mean values using Roese-Gottlieb method (1.63, 1.53 and 1.47\%) for fermented milk beverages prepared with different stabilizers and thickeners. In the present work, in the range of 1.24 to $2.50 \%$, no difference ( $p>0.05$ ) in fat content determination between Gerber and RoeseGottlieb methods was observed (Table 1). So, both could be used to measure fat content in fermented milk beverages. To the best of our knowledge, this is a novel information.

In addition to whey and milk, fermented milk beverages analyzed contain dairy culture, fruit pulp, starch, stabilizer, dyes and potassium sorbate, ingredients that do not contribute to the increase in sample fat. Roese-Gottlieb method is based on the use of ammonium hydroxide to solubilize casein, neutralize acidity and reduce viscosity; in ethyl alcohol to break down the fat-casein emulsion and in ethyl ether-petroleum ether mixture to extract the fat. Petroleum ether is used to decrease the solubility of non-lipid substances (as protein), soluble in ethyl ether. The fat thus extracted is determined gravimetrically. Gerber method is based on the selective attack of organic matter through sulfuric acid, with the exception of fat which will be separated by centrifugation, aided by amyl alcohol, which modifies the surface tension (L. C. G. Costa, 2020).

A high correlation between fat content obtained with each method was observed. The correlation coefficient between these variables was 0.96, which is considered significant $(p<0.0001)$. Figure 1 illustrates the dispersion data of the samples. An ideal situation would match the dotted line. The regression line shows the trend of slightly lower values for the results obtained by butyrometric (Gerber) test. The model found was:

$$
Y=0.93816 X+0.17659\left(R^{2}=0.92\right),
$$

wherein:

$\mathrm{Y}=$ Fat content by Gerber method

$$
X=\text { Fat content by Roese-Gottlieb method }
$$

The fat contents of fermented milk beverages determined by Gerber method were equivalent to those obtained by RoeseGottlieb method. So, the Gerber method can be used to determine the fat content in fermented milk beverages. 
Table 1

Fat contents of thirty fermented milk beverages evaluated by Gerber and Roese-Gottlieb methods

\begin{tabular}{|c|c|c|}
\hline \multirow[b]{2}{*}{ Samples } & \multicolumn{2}{|c|}{ Fat content } \\
\hline & Gerber (\%) & Roese-Gottlieb (\%) \\
\hline 1 & 1.70 & 1.78 \\
\hline 2 & 2.20 & 2.20 \\
\hline 3 & 2.40 & 2.50 \\
\hline 4 & 1.90 & 2.02 \\
\hline 5 & 1.45 & 1.71 \\
\hline 6 & 1.70 & 1.57 \\
\hline 7 & 1.80 & 1.84 \\
\hline 8 & 1.70 & 1.62 \\
\hline 9 & 1.70 & 1.72 \\
\hline 10 & 1.75 & 1.80 \\
\hline 11 & 1.75 & 1.77 \\
\hline 12 & 1.80 & 1.90 \\
\hline 13 & 2.05 & 2.15 \\
\hline 14 & 2.00 & 2.10 \\
\hline 15 & 2.20 & 2.15 \\
\hline 16 & 2.10 & 1.99 \\
\hline 17 & 1.70 & 1.90 \\
\hline 18 & 2.40 & 2.47 \\
\hline 19 & 1.30 & 1.43 \\
\hline 20 & 1.30 & 1.28 \\
\hline 21 & 1.40 & 1.56 \\
\hline 22 & 1.25 & 1.37 \\
\hline 23 & 1.25 & 1.24 \\
\hline 24 & 1.30 & 1.39 \\
\hline 25 & 1.70 & 1.82 \\
\hline 26 & 1.70 & 1.79 \\
\hline 27 & 2.20 & 2.27 \\
\hline 28 & 1.90 & 1.90 \\
\hline 29 & 1.60 & 1.83 \\
\hline 30 & 1.80 & 1.95 \\
\hline Means & $1.77 \mathrm{a} \pm 0.33$ & $1.83 a \pm 0.32$ \\
\hline
\end{tabular}

Means followed by the same letter do not differ by $t$ test $(p>0.05)$. 


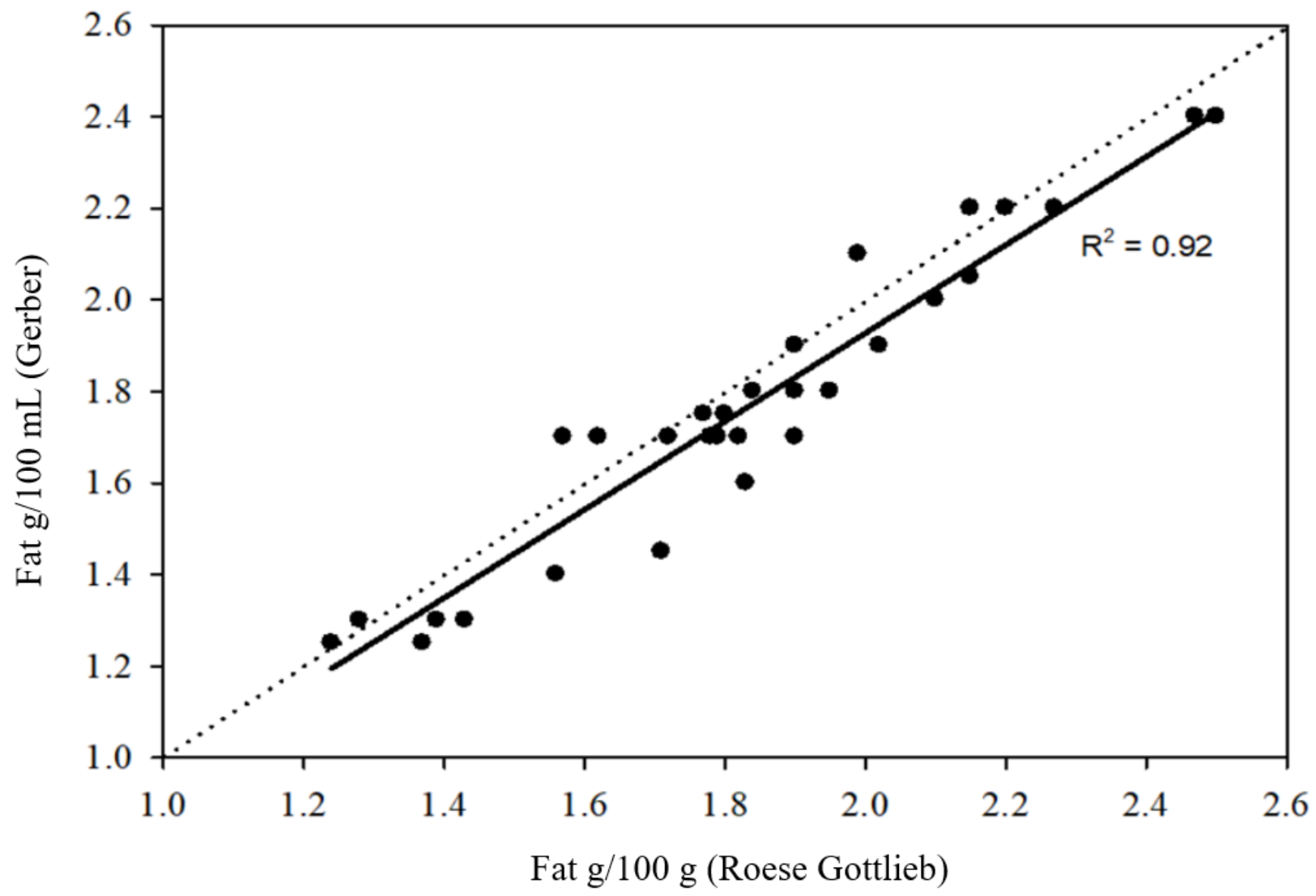

Figure 1. Fat content of thirty samples of fermented milk beverages and mean results analyzed by Gerber (butyrometric) and Roese-Gottlieb (reference) methods.

\section{Acknowledgements}

To Conselho Nacional de Desenvolvimento Científico e Tecnológico (CNPq) for granting a scholarship; to Federal Agricultural Defense Laboratory (Laboratório Nacional Agropecuário/ Laboratório Federal de Defesa Agropecuária - LFDA de Minas Gerais), for technical and logistics support.

\section{References}

Almeida, K. E. D., Bonassi, I. A., \& Roça, R. D. O. (2001). Características físicas e químicas de bebidas lácteas fermentadas preparadas com soro de queijo Minas frescal. Food Science and Technology, 21(2), 187-192. doi: 10.1590/S0101-20 612001000200012

Andrade, E. H. P., Silva, N. M. A., Resende, M. F. S., Souza, M. R., Fonseca, L. M., Cerqueira, M. M. O. P.,... Leite, M. O. (2015). Microbiological and physical-chemical characteristics of fermented milk beverages. Arquivo Brasileiro de Medicina Veterinária e Zootecnia, 67(6), 1735-1742. doi: 10.1590/1678-4162-8066

Association of Official Analytical Chemists (2012). Official methods of analysis of AOAC International. Gaithersburg, Maryland: AOAC International. 
Costa, A. V. S., Nicolau, E. S., Torres, M. C. L., Fernandes, P. R., Rosa, S. I. R., \& Nascimento, R. C. (2013). Desenvolvimento e caracterização físicoquímica, microbiológica e sensorial de bebida láctea fermentada elaborada com diferentes estabilizantes/espessantes. Semina: Ciências Agrárias, 34(1), 209-226. doi: 10.5 433/1679-0359.2013v34n1p209

Costa, L. C. G., Jr. (2020). Métodos físicoquímicos para controle de qualidade em leite e produtos lácteos. Juiz de Fora, MG: Edição do Autor.

Cunha, T. M., Castro, F. P. de, Barreto, P. L. M., Benedet, H. D., \& Prudêncio, E. S. (2008). Avaliação físico-química, microbiológica e reológica de bebida láctea e leite fermentado adicionados de probióticos. Semina: Ciências Agrárias, 29(1), 103-116. doi: 10.5433/1679-0359.2008v29n1p103

International Organization for Standardization I Interantional Dairy Federation (2008). ISO 2446:2008 (IDF 226:2008): Milk - determination of fat content. ISO 2446:2008 (IDF 226:2008). ISO/IDF. Switzerland: ISO/IDF 2008.

International Organization for Standardization/ Interantional Dairy Federation (2010). ISO 1211:2010 (IDF 1:2010): Milk - Determination of fat content Gravimetric method (Reference method). ISO 1211:2010 (IDF 1:2010). ISO/IDF. Switzerland: ISO/IDF 2010.

Kleyn, D. H., Lynch, J. M., Barbano, D. M., Bloom, M. J., \& Mitchell, M. W. (2001). Determination of fat in raw and processed milks by the Gerber method: collaborative study. Journal of AOAC International, 84(5), 1499-1508. doi: 10.1093/jaoac/84.5.1499
Ministério da Agricultra, Pecuária e do Abastecimento (2018). Instrução Normativa $n^{\circ} 30$, de 26 de junho de 2018. Estabelece como oficiais os métodos constantes do Manual de Métodos Oficiais paraAnálisedeAlimentosdeOrigemAnimal para realização de ensaios em amostras de produtos de origem animal, oriundas dos programas e controles oficiais do MAPA, cuja adoção é compulsória pelos laboratórios integrantes da Rede Nacional de Laboratórios Agropecuários do Sistema Unificado de Atenção a Sanidade Agropecuária. Recuperado de http:// www.in. gov.br/materia/-/asset_publisher/ KujrwOTZC2Mb/content/id/29896222/ do1-2018-07-13-instrucao-normativa-n30-de-26-de-junho-de-2018-29896212

Ministério da Agricultura, Pecuária e do Abastecimento (2005). Instrução Normativa $n^{\circ} 16$, de 23 de agosto de 2005. Aprova o Regulamento técnico de Identidade e Qualidade de Bebidas Lácteas. Recuperado de http://www. lex.com.br/doc_411405_INSTRUCAO_ NORMATIVA_N_16_DE_23_DE_AGOSTO_ DE 2005

Oliveira, V. M. (2006). Formulação de bebida láctea fermentada com diferentes concentrações de soro de queijo, enriquecida com ferro: caracterização físico-química, análises bacteriológicas e sensoriais. Dissertação de mestrado, Universidade Federal Fluminense, Niterói, RJ, Brasil.

Sampaio, I. B. (2002). Estatística aplicada à experimentação animal (2a ed.). Belo Horizonte, MG: Fundação de Ensino e Pesquisa em Medicina Veterinária e Zootecnia. 
